Article

\title{
Anti-Inflammatory Activity of the Active Compounds of Sanguisorbae Radix in Macrophages and In Vivo Toxicity Evaluation in Zebrafish
}

\author{
Young-Ah Jang ${ }^{1} \mathbb{D}$, Yong Hur ${ }^{2}$ and Jin-Tae Lee ${ }^{3, *}$ \\ 1 Gennolab Co., Ltd., Gyeongbuk 38540, Korea; yaviol@nate.com \\ 2 Apharm Co., Ltd. 559, Dalseo-daero, Dalseo-gu, Daegu 42709, Korea; coo@drnuell.com \\ 3 Department of Cosmeceutical Science, Daegu Haany University, Gyeongbuk 38540, Korea \\ * Correspondence: jtleecosmetics@gmail.com; Tel.: +82-010-5594-8079
}

Received: 29 October 2019; Accepted: 29 November 2019; Published: 4 December 2019

check for updates

\begin{abstract}
Sanguisorbae Radix (SR) is the root of the Sanguisorba officinalis L., a plant native to Asian countries and used in traditional medicine. We isolated the active components of SR and investigated their anti-inflammatory potential. Quercetin (QC), (+)-catechin (CC), and gallic acid (GA) were isolated from acetone extracts of SR. To elucidate the molecular mechanism by which these compounds suppress inflammation, we analyzed the transcriptional up-regulation of inflammatory mediators, such as nuclear factor-kappa B (NF- $\mathrm{kB}$ ) and its target genes, inducible NOS (iNOS), and cyclooxygenase (COX)-2, in lipopolysaccharide (LPS)-stimulated macrophage RAW264.7 cells. Notably, QC, CC, and GA were found to inhibit the production of nitric oxide, tumor necrosis factor-alpha, and prostaglandin in a dose-dependent manner. Western blot results indicate that the compounds decreased the expression of iNOS and COX-2 proteins. Furthermore, the compounds decreased phosphorylation of IKK, IKB, ERK, p-38, and JNK proteins in LPS-induced cells. The results support the notion that QC, CC, and GA can potently inhibit the inflammatory response, with QC showing the highest anti-inflammatory activity. In in vivo toxicity studies in zebrafish (Danio rerio), QC showed no toxicity up to $25 \mu \mathrm{g} / \mathrm{mL}$. Therefore, QC has non-toxic potential as a skin anti-inflammatory biomaterial.
\end{abstract}

Keywords: anti-inflammatory biomaterial; macrophages; Sanguisorba officinalis; Sanguisorbae Radix

\section{Introduction}

Inflammation is a response to injury caused by harmful physical or chemical stimuli or microbiological toxins, and occurs in numerous pathologies, such as asthma, arthritis, multiple sclerosis, atherosclerosis, and inflammatory bowel diseases [1,2]. There are three types of mammalian nitric oxide synthase (NOS)—neuronal NOS (nNOS), endothelial NOS (eNOS), and inducible NOS (iNOS). Of these, the iNOS is involved in inflammatory reactions [3]. Nitric oxide (NO) generated by the iNOS isoform is necessary for the innate immune and inflammatory responses of hosts to various pathogens and microorganisms [4,5]. However, excessive production of NO is regarded as a pro-inflammatory mediator that induces inflammation in abnormal physiological situations [6]. Therefore, therapeutic agents that inhibit iNOS may effectively ameliorate these inflammatory conditions. Lipopolysaccharide (LPS)-induced gene products include pro-inflammatory cytokines, such as tumor necrosis factor-alpha (TNF)- $\alpha$ and interleukin-6 (IL-6), and adhesion enzymes, such as iNOS and cyclooxygenase-2 (COX)-2 [7]. COX enzymes are known to produce prostaglandins (PGs) that are involved in many physiological events, such as the progression of inflammation, modulation of the inflammatory response, and transmission of pain [8]. COX-1 is typically expressed 
in most tissues, which is expected given that COX-1 maintains housekeeping physiological functions. In contrast, COX-2 is only expressed in some tissues and is transiently induced by growth factors, pro-inflammatory cytokines, tumor promoters, and bacterial toxins [9]. Nuclear factor-kappa B (NF- $\mathrm{B}$ ) is a DNA transcription factor that plays a vital role in the expression of various genes involved in the inflammatory response [10-12]. Inactive NF- $\kappa B$ is bound to its inhibitory subunit I $\mathrm{B}$, and the complexes are sequestered in the cytoplasm. Upon stimulation, IкB proteins are phosphorylated, ubiquitinated, and degraded, allowing NF- $\mathrm{BB}$ to translocate to the nucleus, where it can bind to specific DNA sequences located in the promoter regions of target genes, thereby activating gene transcription $[13,14]$. Recently, many studies demonstrated the role of phytochemicals in anti-inflammatory activity via NF-кB pathway down-regulation [15]. Mitogen-activated protein kinases (MAPKs) have essential functions in the regulation of cell differentiation, cell growth, and cellular responses to cytokines. The MAPK cascades are critical signaling pathways in the immune system and include p38 MAPK, extracellular signal-regulated kinase (ERK), and c-jun N-terminal kinase (JNK) [16]. One of the main functions of MAPK is the activation of transcription factors, some of which increase the expression of pro-inflammatory cytokines [17]. Cytokine-mediated host defense mechanisms induce significant cell and organ injury and play crucial roles in the pathophysiology of sepsis [18].

Sanguisorbae Radix (SR), the dried root of Sanguisorba officinalis L., has hemostatic, analgesic, and astringent properties and has been used in traditional Chinese medicine for the treatment of burns, scalds, inflammation, and internal hemorrhage [19-21]. SR is also used to control bloody pus, treat boils, repair damaged tissue, relieve alcohol poisoning, quench one's thirst, and relieve eye pain [22]. Until now, saponin components such as triterpenes and their glycosides (e.g., ziyuglycoside I) and disaccharide (5-O-alpha-D-(3-C-hydroxymethyl)lyxofuranosyl-beta-D-(2-C-hydroxymethyl) arabino furanose) have been reported as the major active compounds of SR that confer these in vitro and in vivo pharmacological effects [22-25]. Although numerous activities of this plant have been reported and published to date, research on the safety of SR has been limited. Zebrafish are economical with regards to maintenance because it requires simpler breeding facilities, and its feed is less expensive than that of other model species. It produces 200-300 embryos with single external fertilization, which makes it suitable for toxicity assessment [26]. Thus, we used the zebrafish (Danio rerio) embryo model to investigate the potential anti-inflammatory mechanism of SR against LPS-induced inflammatory response in macrophages, to evaluate the root as a potential safe cosmetic material.

\section{Materials and Methods}

\subsection{Materials and Reagents}

RAW264.7 cells were obtained from the Korean Cell Line Bank (KCLB, Seoul, Korea). Dulbecco's Modified Eagle <edium (DMEM), fetal bovine serum (FBS), and penicillin/streptomycin were purchased from Gibco BRL Co. (Grand Island, NY, USA). Lipopolysaccharide (LPS), 3-[4,5-dimethylthiazol-2-yl]-2,5-diphenyl tetrazolium bromide (MTT), acrylamide, and N,N'-bis-methylene-acrylamide were purchased from Sigma-Aldrich Corp. (St, Louis, MO, USA). The iNOS, COX-2, IKK, p-IKK, IкB, p-IкB, ERK, p-ERK, p-38, p-p-38, JNK, p-JNK, and $\beta$-actin monoclonal antibodies and the secondary antibody were purchased from Santa Cruz Biotechnology, Inc., (Santa Cruz, CA, USA). Prostaglandin (PGE 2 ) and TNF- $\alpha$ for ELISA Kits were purchased from R\&D Systems Inc. (Minneapolis, MN, USA). Halt ${ }^{\mathrm{TM}}$ Protease Inhibitor Cocktail Kits and BSA kits were purchased from Thermo Fisher Scientific (Rockford, IL, USA). GoScript ${ }^{\mathrm{TM}}$ Reverse Transcriptase and GoTaq®Flexi DNA Polymerase were purchased from Promega Corporation (Madison, WI, USA).

\subsection{Sample Preparation}

SR was obtained from Andong City, Kyung-Buk, Korea. The powdered roots of SR were extracted with $70 \%$ acetone at $20^{\circ} \mathrm{C}$ for 3 days; the solution was filtered using a filter paper (Whatman No. 2, Tokyo, Japan) and the obtained acetone extract was concentrated under reduced pressure. The acetone extract 
was then dissolved in chloroform in a separatory funnel, and further fractionated by successive solvent extraction with ethyl acetate and n-butanol saturated with $\mathrm{H}_{2} \mathrm{O}$. The n-butanol fraction was fractionated by Diaion HP-20 column chromatography, with stepwise elution of $\mathrm{H}_{2} \mathrm{O}-\mathrm{MeOH}$ (100:1-1:100) to obtain separated active fractions. To determine the structure of the compounds obtained, ${ }^{1} \mathrm{H}-$ and ${ }^{13} \mathrm{C}-\mathrm{NMR}$ were measured, and the structure of individual substances was determined Quercetin (1). Yellow amorphous powder ${ }^{1} \mathrm{H}-\mathrm{NMR}\left(500 \mathrm{MHz}, \mathrm{MeOH}-\mathrm{d}_{6}\right): \delta 7.79\left(1 \mathrm{H}, \mathrm{d}, \mathrm{J}=2.3 \mathrm{~Hz}, \mathrm{H}-2^{\prime}\right), 7.69$ (1H, dd, $\left.\mathrm{J}=2.3,8.5 \mathrm{~Hz}, \mathrm{H}-6^{\prime}\right), 6.99\left(1 \mathrm{H}, \mathrm{d}, \mathrm{J}=8.5 \mathrm{~Hz}, \mathrm{H}-5^{\prime}\right) 6.55(1 \mathrm{H}, \mathrm{d}, \mathrm{J}=2.0 \mathrm{~Hz}, \mathrm{H}-6) 6.25(1 \mathrm{H}, \mathrm{d}, \mathrm{J}=2.0 \mathrm{~Hz}$, H-8). ${ }^{13} \mathrm{C}-\mathrm{NMR}\left(125 \mathrm{MHz}, \mathrm{MeOH}-\mathrm{d}_{6}\right): \delta 175.9$ (C-4), 163.9 (C-7), $160.8\left(\mathrm{C}-5^{\prime}\right), 156.2(\mathrm{C}-9), 147.7\left(\mathrm{C}-4^{\prime}\right)$, 146.8 (C-2), 145.1 (C-3'), 135.8 (C-3), $121.9\left(\mathrm{C}-1^{\prime}\right), 120.0\left(\mathrm{C}-6^{\prime}\right), 115.6\left(\mathrm{C}-5^{\prime}\right), 115.1\left(\mathrm{C}-2^{\prime}\right), 103.1(\mathrm{C}-10)$, 98.2 (C-6), 93.4 (C-8). (+)-Catechin (2). Brown amorphous powder ${ }^{1} \mathrm{H}-\mathrm{NMR}\left(500 \mathrm{MHz}, \mathrm{MeOH}-\mathrm{d}_{6}\right)$ : $\delta 6.84\left(1 \mathrm{H}, \mathrm{dd}, \mathrm{J}=8.0,2.0 \mathrm{~Hz}, \mathrm{H}-6^{\prime}\right), 6.76\left(1 \mathrm{H}, \mathrm{dd}, \mathrm{J}=2.0 \mathrm{~Hz}, \mathrm{H}-2^{\prime}\right), 6.75\left(1 \mathrm{H}, \mathrm{d}, \mathrm{J}=8.0 \mathrm{~Hz}, \mathrm{H}-5^{\prime}\right)$, $5.93(1 \mathrm{H}, \mathrm{d}, \mathrm{J}=2.0 \mathrm{~Hz}, \mathrm{H}-6), 5.86(1 \mathrm{H}, \mathrm{d}, \mathrm{J}=2.0 \mathrm{~Hz}, \mathrm{H}-8), 4.57$ (1H, d, J = $7.5 \mathrm{~Hz}, \mathrm{H}-2), 3.98$ (1H, m, H-3), 2.85 (1H, dd, J = 16.0, $5.5 \mathrm{~Hz}, \mathrm{H}-4 \mathrm{ax}), 2.50(1 \mathrm{H}, \mathrm{dd}, \mathrm{J}=16.0,5.5 \mathrm{~Hz}, \mathrm{H}-4 \mathrm{eq}) .{ }^{13} \mathrm{C}-\mathrm{NMR}(125 \mathrm{MHz}$, MeOH-d 6 ): $\delta 157.9(\mathrm{C}-7), 157.6$ (C-5), 157.0 (C-9), $146.3\left(\mathrm{C}-3^{\prime}\right), 146.3\left(\mathrm{C}-4^{\prime}\right), 132.3\left(\mathrm{C}-1^{\prime}\right), 120.1\left(\mathrm{C}-6^{\prime}\right)$ $116.1\left({\mathrm{C}-5^{\prime}}^{\prime}\right), 115.3$ (C-2'), 100.9 (C-10), 96.3 (C-6), 95.9 (C-8), 83.0 (C-2), 68.9 (C-3), 28.6 (C-4). Gallic acid (3). White amorphous powder ${ }^{1} \mathrm{H}-\mathrm{NMR}\left(500 \mathrm{MHz}, \mathrm{MeOH}-\mathrm{d}_{6}\right): \delta 7.15(2 \mathrm{H}, \mathrm{s}, \mathrm{H}-2,6) .{ }^{13} \mathrm{C}-\mathrm{NMR}$ $\left(125 \mathrm{MHz}, \mathrm{MeOH}-\mathrm{d}_{6}\right): \delta 169.1$ (C-7), 145.7 (C-3, 5), 138.7 (C-4), $121.4(\mathrm{C}-1), 109.9(\mathrm{C}-2,6)$. In this study, three compounds-quercetin (QC), (+)- catechin (CC), and gallic acid (GA)—obtained from SR were used. These compounds were stored in a refrigerator at $4{ }^{\circ} \mathrm{C}$ until use.

\subsection{MTT Assay}

Cells were uniformly dispensed in a 96-well plate $(0.18 \mathrm{~mL})$ at a density of $5 \times 10^{3}$ cells/well. QC, CC, and GA were prepared at concentrations of 5, 10, 25, 50, 75, and $100 \mu \mathrm{g} / \mathrm{mL}$, and $0.02 \mathrm{~mL}$ of the solution was added. Then, the cells were cultured in a $5 \% \mathrm{CO}_{2}$ incubator at $37^{\circ} \mathrm{C}$ for $24 \mathrm{~h}$. Next, $0.02 \mathrm{~mL}$ MTT solution prepared at a concentration of $5 \mathrm{mg} / \mathrm{mL}$ was added, and the mixture was cultured for $4 \mathrm{~h}$. Following incubation, the culture solution was removed, and $0.15 \mathrm{~mL}$ DMSO was added to each well. After incubation at room temperature for $15 \mathrm{~min}$, absorbance was measured at $540 \mathrm{~nm}$ with a Microplate Reader (Winooski, VT, USA). Cell viability was calculated as a percentage of control absorbance.

\subsection{Measurement of NO, PGE2, and TNF- $\alpha$}

Cells were plated at a density of $2 \times 10^{5}$ cells/well in a 24 -well plate. Cells were induced with LPS $(1 \mu \mathrm{g} / \mathrm{mL})$ and treated with either the control, QC, CC, or GA at concentrations of 10, 25, and $50 \mu \mathrm{g} / \mathrm{mL}$ and cultured. The supernatant was collected, and the inhibitory effect of samples on NO, $\mathrm{PGE}_{2}$, and TNF- $\alpha$ cytokine production was determined using the Griess reagent enzyme and ELISA kit (Minneapolis, MN, USA), according to the manufacturer's instructions.

\subsection{Western Blotting}

RAW264.7 cells were uniformly dispensed in a 6-well plate at a density of $1 \times 10^{5}$ cells/well and cultured for $24 \mathrm{~h}$. Then, cells were induced with LPS $(1 \mu \mathrm{g} / \mathrm{mL})$ and treated with the control or QC, CC, or GA at concentrations of 10,25 , and $50 \mu \mathrm{g} / \mathrm{mL}$ and cultured. Protein lysates were obtained by incubating the culture with RIPA lysis buffer (Pierce, IL, USA) for $1 \mathrm{~h}$, followed by centrifugation at $12,000 \mathrm{rpm}$ for $30 \mathrm{~min}$ at $4^{\circ} \mathrm{C}$. Then, proteins were quantified by Bradford assay (Hercules, CA, USA) according to the manufacturer's instruction. Equal proteins were electrophoresed using $10 \%$ sodium dodecyl sulfate-polyacrylamide gel electrophoresis and transferred to a PVDF membrane (Amersham Pharmacia Biotech, Buckinghamshire, UK) at $60 \mathrm{~V}$ for $3 \mathrm{~h}$. After blocking with tris buffer solution containing 5\% skim milk for $1 \mathrm{~h}$, the membrane was incubated with dilution of polyclonal antibodies for iNOS, COX-2, IKK, p-IKK, IKB, p-IкB, ERK, p-ERK, p-38, p-p-38, JNK, p-JNK, and $\beta$-actin. After extensive washes, the membrane was incubated with the secondary antibody (1:1000 dilution) for $1 \mathrm{~h}$ at room temperature. Next, the cells were reacted with Immobilon Western Chemiluminescent 
HRP substrate (Millipore, MA, USA) and protein levels were analyzed using EZ-Capture MG (ATTO Corporation, Tokyo, Japan).

\subsection{RNA Isolation and RT-PCR}

Total RNA was isolated using the TRIsolution ${ }^{\mathrm{TM}}$ Santa Cruz Biotechnology, Inc. (Santa Cruz, CA, USA), according to the manufacturer's instructions. One milliliter of Trizol reagent was added to the cells. After the cells were dissolved and kept at room temperature for $5 \mathrm{~min}, 0.2 \mathrm{~mL}$ of chloroform was added and mixed well. The cells were then centrifuged at $12,000 \times g$ for $10 \mathrm{~min}$. The isolated RNA was dissolved in distilled water containing diethyl pyrocarbonate and the purity of RNA was measured using the ELISA reader. Then, the concentration of RNA was calculated and used for the experiment. GoScript ${ }^{\mathrm{TM}}$ Reverse Transcriptase was used for cDNA synthesis, and PCR was performed using GoTaq®Flexi DNA Polymerase and specific primers. The amplified cDNA was separated by electrophoresis on a $1.5 \%$ agarose gel and visualized by the electrophoresis EZ-Capture MG image analyzer.

\subsection{Zebrafish Breeding Conditions and Embryo Acquisition}

Zebrafish were obtained from the Division of Biomedical \& Cosmetics, Mokwon University, Korea, and were used during the breeding period. All experimental protocols were approved and conducted according to the guidelines and regulations of the Animal Ethics Committee of Mokwon University. Wild-type zebrafish were provided by the Zebrafish Center for Disease Modeling, Korea. The rearing condition was kept constant at $28 \pm 1{ }^{\circ} \mathrm{C}$ with a $16 \mathrm{~h} / 8 \mathrm{~h}$ light/dark cycle (Rotifer continuous culture system, GDBC, Korea). They were fed brine shrimp (Ocean Star International, Utah, USA). Female and male fish with at least five spawning experiences were fed adequate feed the day before spawning; $24 \mathrm{~h}$ later, irradiation of light was used to produce embryos. The produced embryos were incubated at $28 \pm 1^{\circ} \mathrm{C}$ for 2 days in pre-manufactured egg water (sea salt solution, Aquarium Systems, France) to avoid exceeding a maximum of 50 eggs in a $100-\mathrm{mm}$ petri dish, and the egg water was replaced periodically. Figure 1 shows the Zebrafish model.
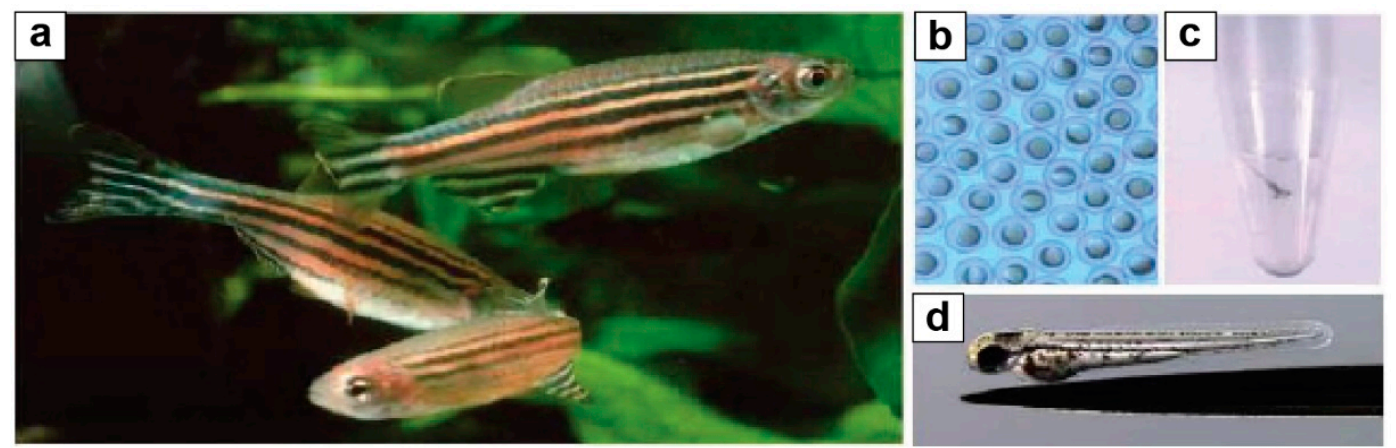

Figure 1. Danio rerio animal model. (a) D. rerio is a small tropical fish of the Cyprinidae family, $4-5 \mathrm{~cm}$ in length; (b) $6 \mathrm{~h}$ of embryonic development, embryos are $\sim 0.7 \mathrm{~mm}$ across; (c) 1-week-old larva swimming in E. tube; (d) embryonic after two days of development, placed on needlepoint.

\subsection{Zebra Fish Embryo Toxicity Test}

Mature male and female zebrafish were separated in the tank for egg collection. After $24 \mathrm{~h}$, they were put together, and eggs were collected. The culture solution was used as a control. To each well of the 24-well plate, 3 zebrafish eggs were added and treated with different concentrations of QC: 10, 25 , and $50 \mu \mathrm{L} / \mathrm{mL}$. The plate was then placed in the incubator at $28^{\circ} \mathrm{C}$, and the toxicity level of the samples treated with QC was analyzed for coagulation rate and hatching rate at 24,48 , and $72 \mathrm{~h}$ after the QC treatment and compared with control. 


\subsection{Statistical Analysis}

Statistical analysis was performed using SPSS 12.0, and differences were considered significant when $p<0.05,0.01$ after a $t$-test using analysis of variance (ANOVA).

\section{Results and Discussion}

Inflammation is a defensive pathway primarily caused by the action of phagocytic cells, such as macrophages and dendritic cells, which work to protect the body from exogenous pathogens [27]. The innate immune response is part of an appropriate inflammatory reaction that contributes to the development of adaptive immunity. However, excessive and inappropriate inflammatory reactions cause cell necrosis and various chronic diseases [28]. Skin-related diseases are often accompanied by inflammation, which causes aggravation, such as acne and atopy. Studies are being actively conducted to identify natural materials that can alleviate the inflammatory reaction [29]. Herein, we identified three compounds from SR extracts (Figure 2) and then evaluated the toxicity of SR compounds (QC, CC, and GA) at different concentrations against RAW264.7 cells (Figure 3); the cells showed a viability of $>85 \%$ at all concentrations below $50 \mu \mathrm{g} / \mathrm{mL}$. Thus, these compounds were considered non-toxic, and further experiments were conducted using a concentration of $50 \mu \mathrm{g} / \mathrm{mL}$.<smiles>O=c1c(O)c(-c2ccc(O)c(O)c2)oc2cc(O)cc(O)c12</smiles><smiles>CC1=C(c2ccc(O)c(O)c2)Oc2cc(O)cc(O)c2C1</smiles><smiles>O=C(O)c1cc(O)c(O)c(O)c1</smiles>

Figure 2. Structure of (a) quercetin, (b) (+)-catechin, and (c) gallic acid isolated from Sanguisorbae Radix.

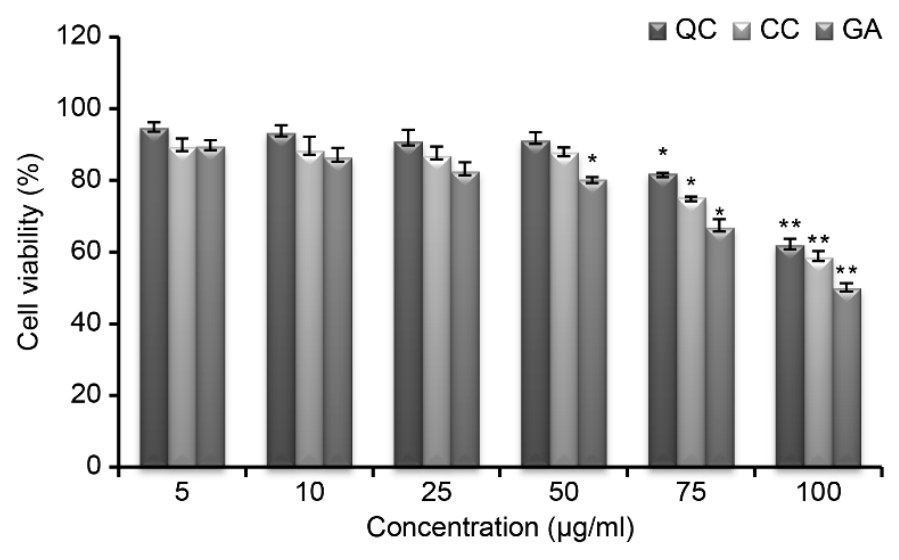

Figure 3. Viability, detected by MTT assay, of RAW264.7 cells after treatment with various concentrations of quercetin (QC), (+)- catechin (CC), and gallic acid (GA), obtained from Sanguisorbae Radix. Data are represented as mean \pm standard error $(n=3)$ of three independent experiments. ${ }^{*} p<0.05,{ }^{* *} p<0.01$, as compared with the control.

Several pro-inflammatory cytokines, such as TNF- $\alpha, \mathrm{PGE}_{2}$, and IL-8, promote systemic inflammation. We measured the production levels of TNF- $\alpha$ and PGE 2 using an ELISA Kit and examined the production of NO using the Griess reagent. As shown in Figure 4a,b, SR markedly blocked the production of these inflammatory mediators in LPS-treated RAW264.7 cells. At $50 \mu \mathrm{g} / \mathrm{mL}$ of QC, PGE 2 levels decreased by $38.8 \%$ and TNF- $\alpha$ levels decreased by $21.9 \%$, which was the highest 
cytokine inhibition activity observed. TNF- $\alpha$ and $\mathrm{PGE}_{2}$ production were also suppressed by $\mathrm{CC}$ and GA treatments in a dose-dependent manner. Additionally, QC was effective at suppressing the release of NO from LPS-induced peritoneal macrophages (Figure 4c).
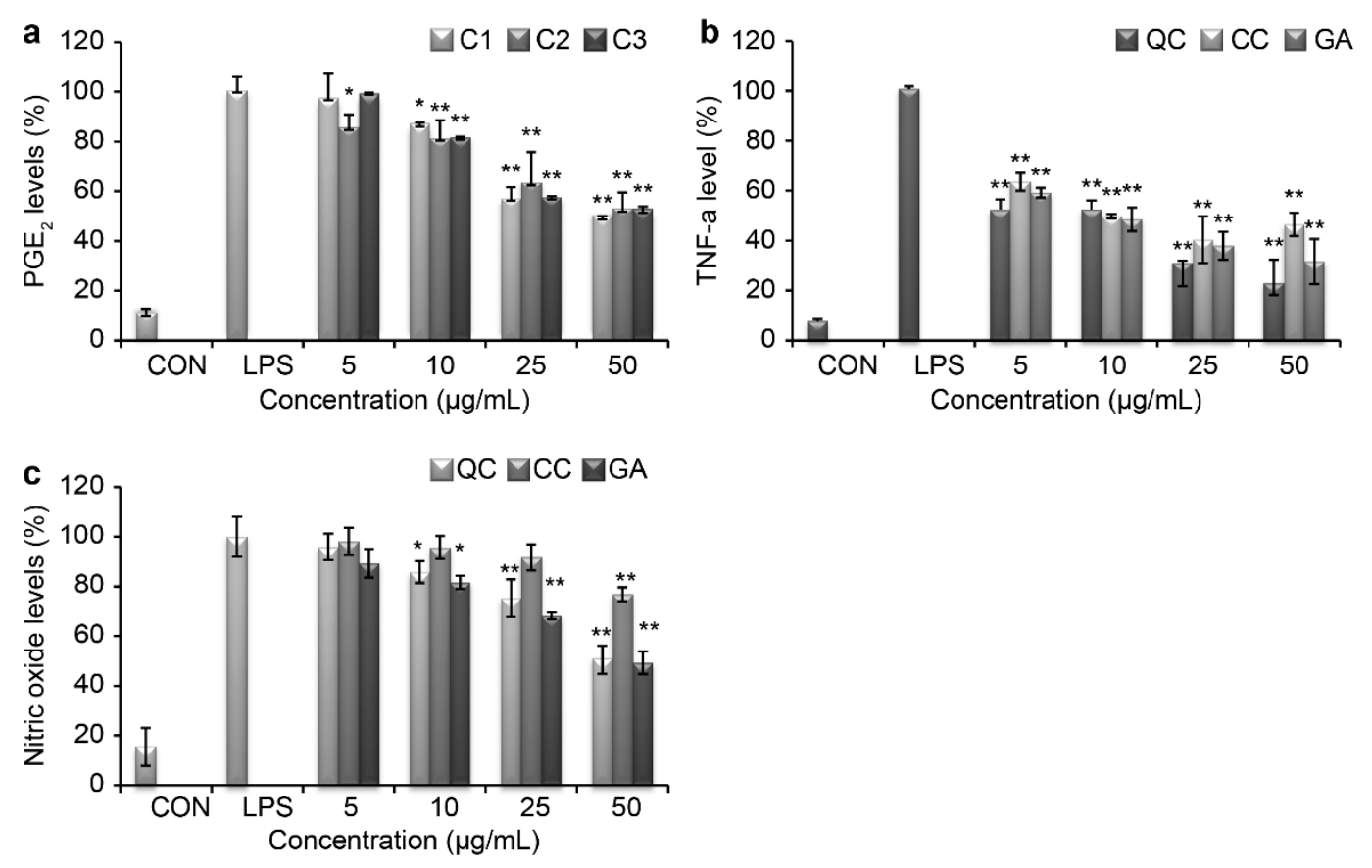

Figure 4. Effect of quercetin (QC), (+)- catechin (CC), and gallic acid (GA) from Sanguisorbae Radix on LPS-induced expression of nitric oxide (NO) in RAW264.7 cells. The cells were incubated for $24 \mathrm{~h}$ in DMEM containing 10\% FBS, and then simultaneously treated with various concentrations of QC, CC, or GA for $24 \mathrm{~h}$. The supernatant was collected from each well, and (a) $\mathrm{PGE}_{2}$ and (b) TNF- $\alpha$ levels were determined by ELISA. (c) NO level was determined by the Griess reagent. Data are represented as mean \pm standard error $(n=3)$ from three independent experiments. ${ }^{*} p<0.01,{ }^{* *} p<0.005$.

To investigate the molecular mechanism through which these compounds suppress inflammation, we measured the mRNA and protein expression levels of iNOS and COX-2. LPS stimulation of RAW264.7 cells markedly increased iNOS and COX-2 production compared with that in the negative control. As shown in Figure 5a, the protein expression level of iNOS was found to be 20.7\%, 36.2\%, and $23.8 \%$ upon treatment with $50 \mu \mathrm{g} / \mathrm{mL}$ QC, CC, and GA, respectively. Similarly, the mRNA expression level of iNOS was found to be $40.6 \%, 53.3 \%$, and $37.3 \%$ after treatment with $50 \mu \mathrm{g} / \mathrm{mL}$ of QC, CC, and GA, respectively (Figure 5b). Thus, treatment with the SR compounds markedly inhibited the LPS-mediated induction of iNOS mRNA and protein expression. 
a
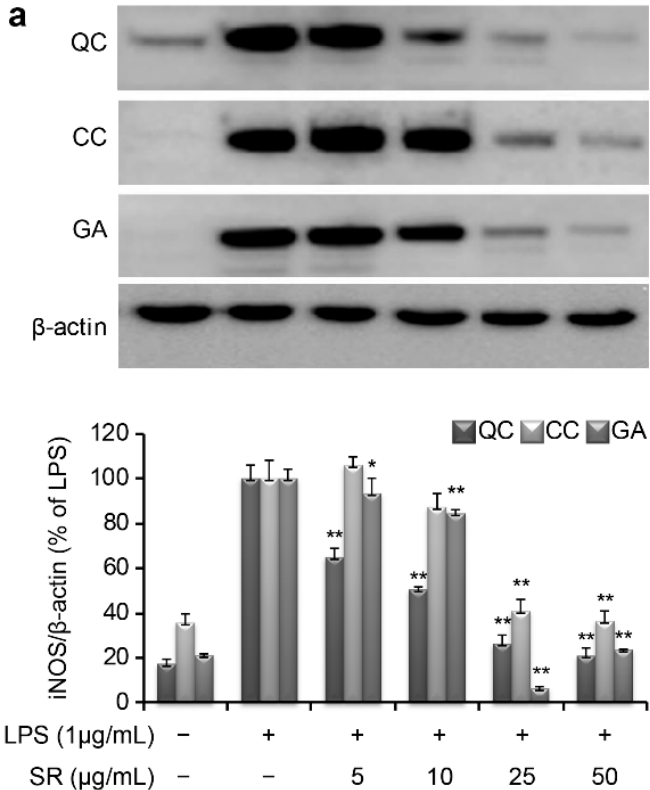

b
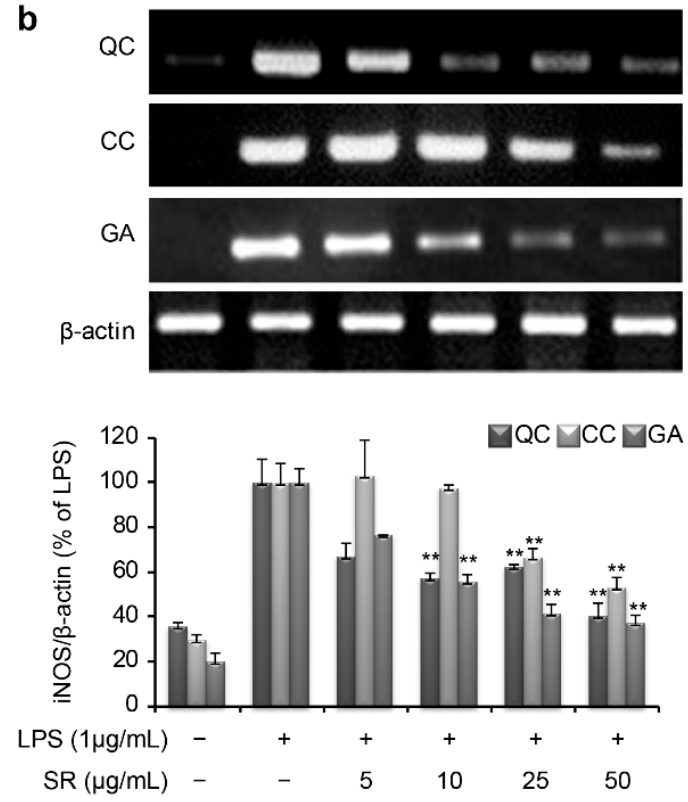

Figure 5. Inhibition of inducible nitric oxide synthase (iNOS) protein (a) and mRNA (b) expression by quercetin (QC), (+)- catechin (CC), or gallic acid (GA) in LPS-stimulated RAW264.7 cells. Cells were pretreated with the indicated concentrations of QC, CC, or GA $1 \mathrm{~h}$ before stimulation with $1 \mu \mathrm{g} / \mathrm{mL}$ LPS and then incubated for $24 \mathrm{~h}$. (a) Cell lysates were electrophoresed, and iNOS expression was detected by a specific antibody. (b) Total RNA was prepared for reverse transcription polymerase chain reaction analysis of iNOS gene expression. Data are represented as mean \pm standard error $(n=3)$ of three independent experiments. ${ }^{*} p<0.05,{ }^{* *} p<0.01$, compared with control.

Similar to iNOS, the COX-2 mRNA and protein levels were markedly induced by LPS stimulation (Figure 6). However, the protein expression level of COX-2 was reduced to $12.4 \%, 44.1 \%$, and $23.8 \%$ upon simultaneous treatment with $50 \mu \mathrm{g} / \mathrm{mL} \mathrm{QC,} \mathrm{CC,} \mathrm{and} \mathrm{GA,} \mathrm{respectively} \mathrm{(Figure} \mathrm{6a).} \mathrm{Consistent}$ with this, the corresponding COX-2 mRNA expression level was reduced to $23.9 \%, 47.8 \%$, and $35.5 \%$ after treatment with $50 \mu \mathrm{g} / \mathrm{mL}$ QC, CC, and GA, respectively (Figure 6b).

Thus, LPS-stimulated macrophages show the rapid induction of genes responsible for production of pro-inflammatory cytokines, such as TNF- $\alpha$ and $\mathrm{PGE}_{2}$, and inflammatory mediators, such as NO. Our data demonstrate that SR markedly inhibited or suppressed these LPS-induced pro-inflammatory effects in RAW264.7 cells at both the mRNA and protein levels. 
a
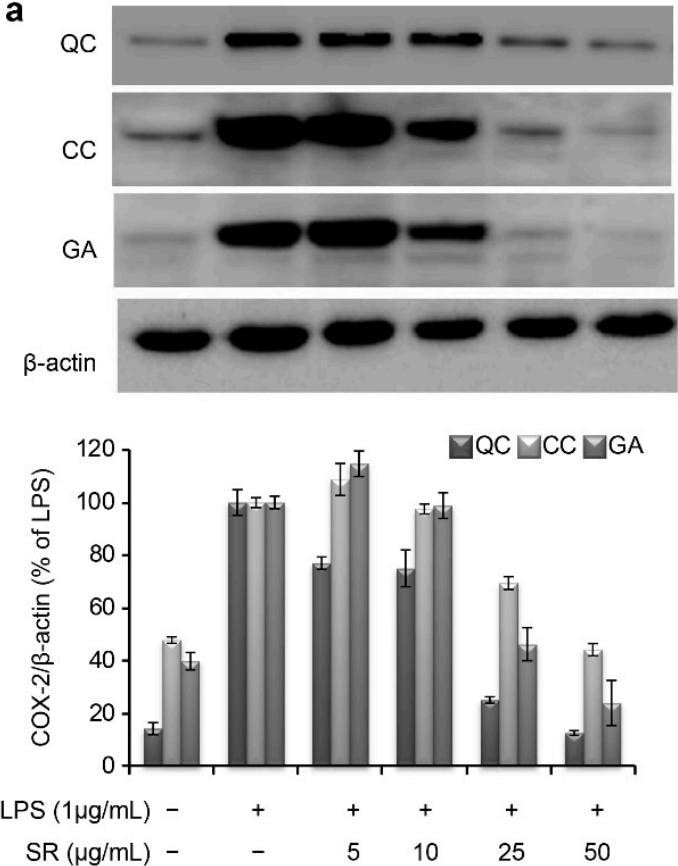

b
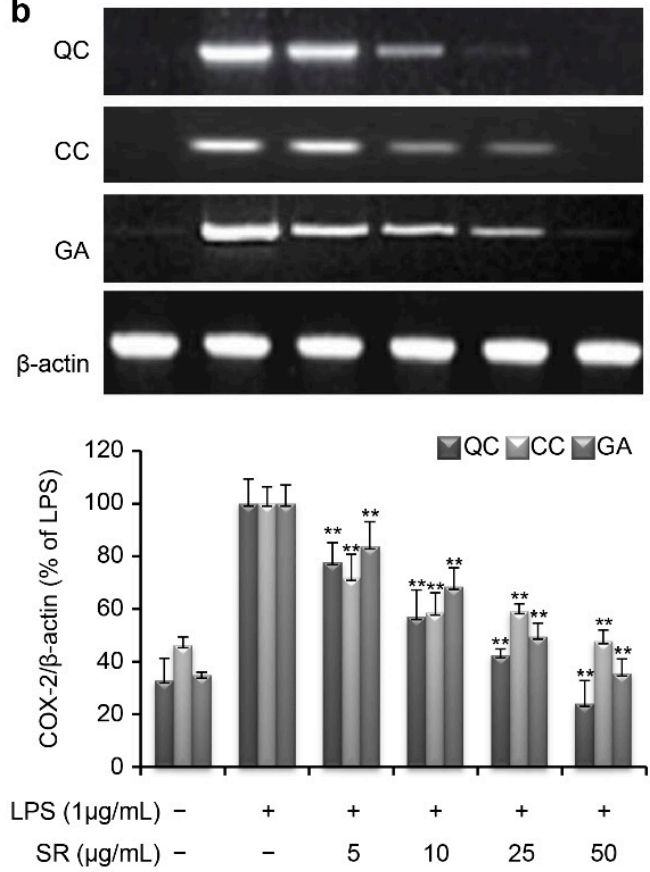

Figure 6. Inhibition of inducible nitric oxide synthase COX-2 protein (a) and mRNA (b) expression by quercetin (QC), (+)- catechin (CC), or gallic acid (GA) in LPS-stimulated RAW264.7 cells. Cells were pretreated with the indicated concentrations of QC, CC, or GA $1 \mathrm{~h}$ before stimulation with $1 \mu \mathrm{g} / \mathrm{mL}$ LPS and then incubated for $24 \mathrm{~h}$. (a) Cell lysates were electrophoresed, and COX-2 expression was detected by a specific antibody. (b) Total RNA was prepared for reverse transcription polymerase chain reaction analysis of COX-2 gene expression. Data are represented as mean \pm standard error $(n=3)$ of three independent experiments. ${ }^{*} p<0.05,{ }^{* *} p<0.01$, as compared with the control.

A previous study reported that LPS increased activation of NF- $\mathrm{B}$ and regulated the expression of iNOS, COX-2, and other cytokines [30]; thus, NF- $\kappa$ B plays an important role in inflammation. NF- $\kappa B$ binds to inhibitory $\kappa \mathrm{B} \alpha(\mathrm{I} \kappa \mathrm{B} \alpha)$ molecules in the promoter region of an inflammatory response and only becomes active after $I \kappa B \alpha$ is phosphorylated and subsequently degraded; this modification of $I_{\kappa} B \alpha$ occurs at serine 32 and 36 by the IKB kinase (IKK) complex [31]. Thus, we examined the effects of SR on phosphorylation of IKB $\alpha$ and IKK in LPS-induced cells. As a result, treatment with QC, CC, or GA attenuated the phosphorylation of IKB $\alpha$ and IKK in a dose-dependent manner (Figure 7). 

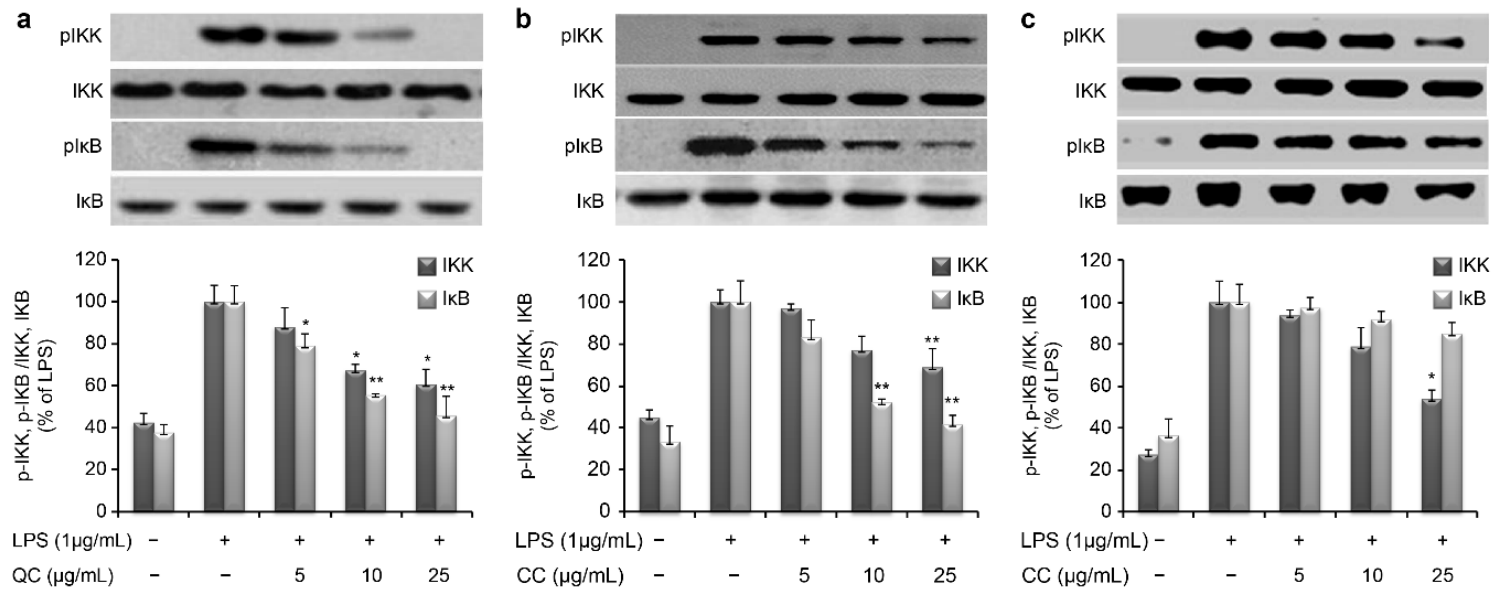

Figure 7. Effect of quercetin (QC), (+)-catechin (CC), and gallic acid (GA) on NF-kB activity in LPS-stimulated RAW264.7 cells. Results are expressed as a ratio of phosphorylated IKK and $\mathrm{I} \kappa \mathrm{B} /$ non-phosphorylated IKK and I $\mathrm{KB}$. Data are represented as mean \pm standard error $(n=3)$ of three independent experiments. ${ }^{*} p<0.05,{ }^{* *} p<0.01$, compared with control.

The MAPK family consists of ERK, p38, and JNK [32]. In our study, SR effectively suppressed the phosphorylation of ERK, p38, and JNK, which is a critical event in the MAPK signal transduction pathway (Figure 8). These data suggest that SR inhibits the production of inflammation by regulating gene expression involved in the NF-KB and MAPK-mediated inflammatory process.

a
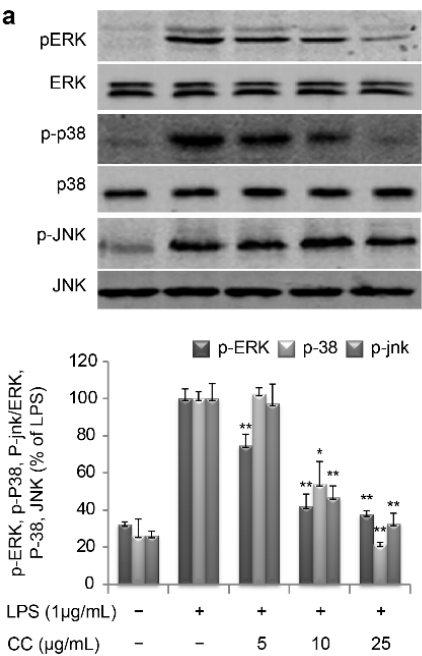

b

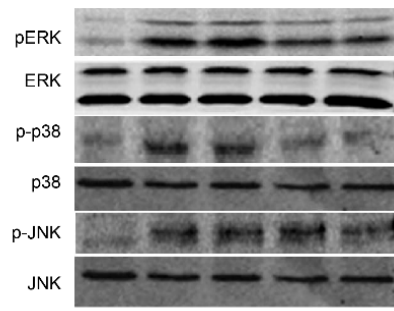

p-ERK $\square$ p-38 $\square$ p-jnk

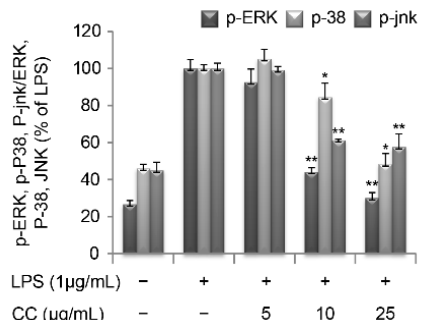

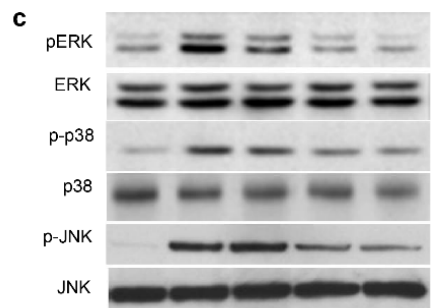

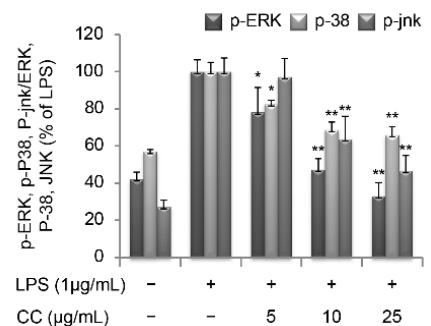

Figure 8. Effect of quercetin (QC), (+)-catechin (CC), and gallic acid (GA) on mitogen-activated protein kinase (MAPK) activity in LPS-stimulated RAW264.7 cells. Results are expressed as a ratio of phosphorylated ERK, p38, and JNK/non-phosphorylated ERK, p38, and JNK. Data are represented as mean \pm standard error $(n=3)$ of three independent experiments. ${ }^{*} p<0.05,{ }^{* *} p<0.01$, compared with control.

To examine the toxicity of QC, zebrafish embryos were treated with $0,10,25$, and 50 ppm of QC $12 \mathrm{~h}$ post-fertilization, and the coagulation rate and hatching rate of embryos were monitored for $72 \mathrm{~h}$ (Figure 9a,b). In the control group, the embryos were treated with egg water 24 and $48 \mathrm{~h}$ post-fertilization, and the coagulation rate was $0 \%$. In contrast, the coagulation rate of the group treated with 50 ppm QC for $72 \mathrm{~h}$ was 33\%. The hatching rate of the embryos from the control group after $48 \mathrm{~h}$ was $100 \%$, while that of the embryos treated with 10, 25, and 50 ppm of QC was $58 \%, 41 \%$, and $33 \%$, 
respectively, indicating a delay in hatching. According to the results, QC qualified as a safe material at a concentration of $50 \mu \mathrm{g} / \mathrm{ml}$ in the safety experiment using the zebrafish model. Nonetheless, the hatching rate was $100 \%$ after $72 \mathrm{~h}$ in these treatment groups, indicating that the QC extract is safe. Moreover, zebrafish embryos treated with $10 \mathrm{ppm}$ and $25 \mathrm{ppm}$ of QC did not coagulate and underwent normal embryogenesis, similar to that in the control group.
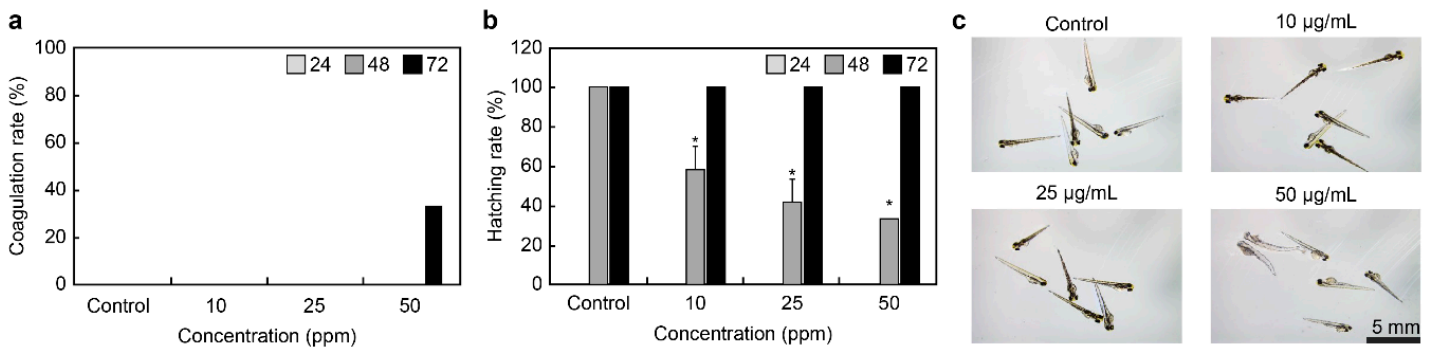

Figure 9. Effect of quercetin (QC) on zebrafish development. (a) Embryo coagulation rate, (b) hatching rate. (c) Representative image of zebrafish treated with control (egg water) or QC at indicated concentrations. Data are represented as mean \pm standard error $(n=3)$ of three independent experiments. * $p<0.05$, compared with control.

Although analysis of the development of zebrafish, when exposed to different concentrations of QC, showed no morphological abnormality at 10 ppm and 25 ppm, yolk swelling and melanin loss were observed at 50 ppm (Figure 9c).

\section{Conclusions}

In this study, we evaluated the anti-inflammatory effects of SR compounds (QC, CC, and GA) using the RAW264.7 cell line and evaluated their in vivo toxicity using zebrafish. Our results show that QC, CC, or GA was able to suppress iNOS and COX-2 expression, and phosphorylation of p38, JNK, and ERK in LPS-stimulated RAW264.7 cells. Furthermore, the application of QC, CC, or GA effectively suppressed pro-inflammatory cytokines (TNF- $\alpha$ and PGE 2 ) and NO expression. Of the three compounds, QC showed the highest anti-inflammatory effect. Besides, the toxicity assessment of QC provided evidence that QC is non-toxic at a concentration lower than $25 \mu \mathrm{g} / \mathrm{mL}$. Therefore, SR has potential applications as a safe anti-inflammatory biomaterial for use in skin-care products.

Author Contributions: Y.-A.J. conceived, designed, and performed the experiments, analyzed the data, and wrote the manuscript. Y.H. reviewed and approved the final manuscript. J.-T.L. designed the manuscript, analyzed the data, and reviewed the final manuscript.

Funding: This research was funded by the Biotherapy Industry Base Construction Project from the Ministry of Trade, Industry, and Energy (MTIE) in 2018, grant number N0001805.

Conflicts of Interest: The authors have no conflicts of interest to declare. The funders of this study had no role in its design or in the collection of data and analysis. The funder did not influence the writing of the manuscript or the decision to publish the results.

\section{References}

1. Shim, S.B. Study on Characterizations of Endemic Natural Substances and Efficacy Evaluation of Formulation Using as Cosmetic Ingredients. Ph.D. Thesis, Department of Chemical Engineering, Graduate School, Hanyang University Seoul, Seoul, Korea, 2012; pp. 12-31.

2. Toltl, L.J.; Swystun, L.L.; Pepler, L.; Liaw, P.C. Protective effects of activated protein C in sepsis. Thromb. Haemost. 2008, 100, 582-592. [CrossRef] [PubMed]

3. Kindt, T.J.; Goldsby, R.A.; Osborne, B.A. Innate Immunity: Tenney S. Kuby Immunology, 6th ed.; W. H. Freeman Company: New York, NY, USA, 2007; pp. 52-73. 
4. Guzik, T.J.; Korbut, R.; Adamek-Guzik, T. Nitric oxide and superoxide in inflammation and immune regulation. J. Physiol. Pharmacol. 2003, 54, 469-487. [PubMed]

5. Rankin, J.A. Biological mediators of acute inflammation. AACN Clin. Issues 2004, 15, 3-17. [CrossRef] [PubMed]

6. MacMicking, J.; Xie, Q.W.; Nathan, C. Nitric oxide and macrophage function. Annu. Rev. Immunol. 1997, 15, 323-350. [CrossRef] [PubMed]

7. Pfeilschifter, J.; Muhl, H. Immunopharmacology: Anti-inflammatory therapy targeting transcription factors. Eur. J. Phamacol. 1999, 375, 237-245. [CrossRef]

8. Sharma, J.N.; Al-Omran, A.; Pavathy, S.S. Role of nitric oxide in inflammatory diseases. Inflammopharmacology 2007, 15, 252-259. [CrossRef]

9. Ahn, K.S.; Aggarwal, B.B. Transcription factor NF-\{kappa\} B a sensor for smoke and stress signals. Ann. J. N. Y. Acad. Sci. 2005, 1056, 218-233. [CrossRef]

10. Vane, J.R.; Botting, R.M. Anti-inflammatory drugs and their mechanism of action. Inflamm. Res. 1998, 47, 78-87. [CrossRef]

11. Prescott, S.M.; Fitzpatrick, F.A. Cyclooxygenase-2 and carcinogenesis. Biochim. Biophys. Acta Rev. Cancer 2000, 1470, M69-M78. [CrossRef]

12. Tageder, I.; Pfeilschifter, J.; Geisslinger, G. Cyclooxygenase-independent actions of cyclooxygenase inhibitors. FASEB J. 2001, 15, 2057-2072. [CrossRef]

13. Ghosh, S.; May, M.J.; Kopp, E.B. NF-kappa B and Rel proteins: Evolutionarily conserved mediators of immune responses. Annu. Rev. Immunol. 1998, 16, 225-260. [CrossRef] [PubMed]

14. Thanos, D.; Maniatis, T. NF-kappa B: A lesson in family values. Cell 1995, 80, 529-532. [CrossRef]

15. Baldwin, A.S., Jr. The NF-kappa B and I kappa B proteins: New discoveries and insights. Annu. Rev. Immunol. 1996, 14, 649-681. [CrossRef]

16. Finco, T.S.; Baldwin, A.S. Mechanistic aspects of NF-kappa B regulation the emerging role of phosphorylation and proteolysis. Immunity 1995, 3, 263-272. [CrossRef]

17. Kundu, J.K.; Surh, Y.J. Breaking the relay in deregulated cellular signal transduction as a rationale for chemo prevention with anti-inflammatory phytochemicals. Mutat. Res. Fundam. Mol. Mech. Mutagen. 2005, 591, 123-146. [CrossRef]

18. Seger, R.; Krebs, E.G. The MAPK signaling cascade. FASEB J. 1995, 9, 726-735. [CrossRef]

19. Baldassare, J.J.; Bi, Y.; Bellone, C.J. The role of p38 mitogen-activated protein kinase in iL-1 beta transcription. J. Immunol. 1999, 162, 5367-5373.

20. Guo, D.L.; Chen, J.F.; Tan, L.; Jin, M.Y.; Ju, F.; Cao, Z.X.; Deng, F.; Wang, L.N.; Gu, Y.G.; Deng, Y. Terpene Glycosides from Sanguisorba officinalis and Their Anti-Inflammatory Effects. Molecules 2019, 24, 2906. [CrossRef]

21. OECD (Organization for Economic Cooperation and Development). Draft Proposal for a New Guideline: Fish Embryo Toxicity (FET) Test. 2006. Available online: http://www.oecd.org/chemicalsafety/testing/36817070.pdf (accessed on 3 October 2019).

22. Kwon, W.J.; Whang, W.K.; Kim, H. Constituents of Sanguisorba hakusanensis leaves. Yathak Hoeji 1996, 40, 262-272.

23. East, J. The effect of certain plant preparations on the fertility of laboratory mammals. J. Endocrinol. 1995, 12, 273-276. [CrossRef]

24. Hong, J.; Yang, G.; Kim, Y.B.; Eom, S.H.; Lew, J.; Kang, H. Anti-Inflammatory Activity of Cinnamon Water Extract in vivo and in vitro LPS-Induced Models. BMC Complem. Altern. Med. 2012, 12, 237. [CrossRef]

25. Bogdan, C. Nitric oxide and the immune response. Nat. Immunol. 2001, 2, 907-916. [CrossRef]

26. Jong, H.P.; Jee, A.H.; Jin, S.K.; Jeon, O.M. Pharmacognostical studies on the "O-I-Pul". Korean J. Pharmacogn. 1997, 28, 124-130.

27. Park, K.H.; Koh, D.S.; Kim, K.J.; Park, J.; Lim, Y.H. Antiallergic activity of a disaccharide isolated from Sanguisorba officinalis. Phytother. Res. 2004, 18, 658-662. [CrossRef]

28. Cho, J.Y.; Yoo, E.S.; Cha, B.C.; Park, H.J.; Rhee, M.H.; Han, Y.N. The inhibitory effect of triterpenoid glycosides originating from Sanguisorba officinalis on tissue factor activity and the production of TNF-alpha. Planta Medica 2006, 72, 1279-1284. [CrossRef] 
29. Ban, J.Y.; Nguyen, H.T.; Lee, H.J.; Cho, S.O.; Ju, H.S.; Kim, J.Y.; Bae, K.; Song, K.S.; Seong, Y.H. Neuroprotective properties of gallic acid from Sanguisorbae radix on amyloid beta protein (25-35)-induced toxicity in cultured rat cortical neurons. Biol. Pharm. Bull. 2008, 31, 149-153. [CrossRef]

30. Kim, Y.H.; Chung, C.B.; Kim, J.G.; Ko, K.I.; Park, S.H.; Kim, J.H.; Eom, S.Y.; Kim, Y.S.; Hwang, Y.I.; Kim, K.H. Anti-wrinkle activity of ziyuglycoside I isolated from a Sanguisorba officinalis root extract and its application as a cosmeceutical ingredient. Biosci. Biotechnol. Biochem. 2008, 72, 303-311. [CrossRef]

31. Martin, P.; Leibovich, S.J. Inflammatory cells during wound repair: The good, the bad and the ugly. Trends Cell Biol. 2005, 15, 599-607. [CrossRef]

32. Fan, G.; Zhang, Y.; Jiang, X.; Zhu, Y.; Wang, B.; Su, L.; Cao, W.; Zhang, H.; Gao, X. Anti-Inflammatory Activity of Baicalein in LPS-Stimulated RAW264. 7 Macrophages via Estrogen Receptor and NF- $\mathrm{kB}-$ Dependent Pathways. Inflammation 2013, 36, 1584-1591. [CrossRef]

(C) 2019 by the authors. Licensee MDPI, Basel, Switzerland. This article is an open access article distributed under the terms and conditions of the Creative Commons Attribution (CC BY) license (http://creativecommons.org/licenses/by/4.0/). 